\title{
The Islamist version of utopia: The politics of redesigning space
}

\section{SEVAL ŞAHİN - DIDDEM ARDALI BÜYÜKARMAN}

DOI: https://doi.org/10.31577/WLS.2021.13.2.4

Even though it is a no-place by its very nature, a utopia locates a society as an imagined ideal in a specific setting. As Fatima Vieira notes in "The Concept of Utopia", "Utopists depart from the observation of the society they live in, note down the aspects that need to be changed and imagine a place where those problems have been solved. Quite often, the imagined society is the opposite of the real one, a kind of inverted image of it" $(2010,8)$. In that sense while utopias might imagine a better way of living in a different place, in an ideal society, maybe even under the reestablished sovereignty of an ancient self-narrative, its hope of realizing such ideals is anchored in a relatable place even if it might be, and often is, a stretch in the form of a metaphor. This article examines two Islamist novels in Turkish, Ali Nar's The Space Farmers (Uzay Çiftçileri, 1988) and Ayşe Şasa's The Novel of the Monkeys (Şebek Romani, 2004), in order to explore how the religious ideologies of the novelists become manifest in their utilization of spatial settings as utopian inverted images of reality. In their utopian imaginary, these two novels propose "the Christian West" as being responsible for the corruption of the world as place and promote its improvement through a transformative wave that will emerge in Turkey and move towards Europe. In such an ideological picture, the spatial settings are loaded with heavily symbolic meanings and emerge as allegories of clashing civilizations. Previous scholars such as Christian Szyska (1995) and Erol Gökşen (2015) have discussed these works within the framework of utopias and dystopias, although Szyska's discussion is limited to Nar's novel and Gökçen does not focus on the concept of place in his study. In their pursuit of utopian places as inverted images of reality and ideological supremacy, the novelists not only denounce the secular Turkey established in 1923 but also tell their desired stories of the rebirth of Islamist power. The ways in which they tell these stories, however, are deeply fraught with ideological problems. Neither of their utopias are just Islamist, i.e. proponents of the spiritual merits, the social practices, and the cultural values of Islam. Instead, they both promote a radical version of it and fervently advocate its supremacy over other belief systems (Toumi 2011, 126-132). ${ }^{1}$ They establish their ideological position clearly by setting their utopic worlds against the West in zealous antagonism and imagine a world in which their form of radical Islam rules.

The genre of utopia appeared in Turkish literature from the 19th century onward in the form of dreams whereby intellectuals such as Namık Kemal and Ziya Paşa ex- 
plored their thoughts on a better world by means of a dream. For instance, in Namik Kemal's Dream (Rüya, 1872), the utopia is a world in which milk flows from the taps in the morning and all the roads run on a rail system. In Ziya Paşa's identically-titled Dream (Rüya, 1868), on the other hand, the character/narrator enters a pool in London, meets the Ottoman Sultan of the time, Abdülaziz, and convinces him that the state of the country is not good. In such utopian dreams, the characters often suddenly find themselves in some other place than they were previously, or they just appear in a world that no one knows about, or they ascend to the sky.

The relationship between utopias and politics continued with the foundation of the modern Turkish Republic in 1923. Paralleling the period's drive to establish a nation-state, writers such as Halide Edip and Yakup Kadri penned their versions of utopia in lieu with that political model. While Halide Edip, in her novel The New Turan (Yeni Turan, 1912), designed a world ruled by the Turks, Yakup Kadri, in his Ankara (1934) portrays the new capital of the young Republic as a highly developed place; all citizens wholeheartedly embrace the new values, and following the revolution of Mustafa Kemal Atatürk, the country is so advanced that it competes with the West.

As can be seen in this brief introduction, the genre of utopia in Turkish literature is intimately related with the political and it is driven not only to criticize the status quo but also to propose a new and better order that is relevant to the ideological perspective in question. This new order might propose the reformation of an old one or the fixing of the present one. Such a stance had a vital impact on the reformulation of places, as spatial settings bear both political references and the broader implications of utopian narratives.

Following the coup of September 12,1980, there has been a marked increase in the rise of Islamist literature in Turkey and writers such as Şule Yüksel Şenler and Minyeli Abdullah explored the rediscovery of Islam by those who previously embraced the modernized and secular lifestyle. In these kinds of works, characters who never received a religious education or who turned faithless are depicted as being transformed with the re-introduction of religion into their lives. These characters begin to practice their religion and perceive the world around them in a different light. Such narratives with their religious messages diversified in the 1990s in terms of their forms and styles, and in the 2000s, the different forms and styles were replaced by different writing modes. In her novels Schrödinger's Cat: Nightmare (Schrödinger'in Kedisi: Kâbus, 1999), and Dream (Rüya, 2001), one of the leading conservative authors, Alev Alatll, criticizes the new world order and proposes a dystopia of Turkish society having lost its native values through modernization. Mukadder Gemici and Handan Acar Yildız also use utopia in their stories, but instead of utilizing it to depict loss of values, they combine it with narratives of the end of the world to re-imagine a metaphoric new world.

Although Ayşe Şasa and Ali Nar were born in the same year (1941) and died only one year apart (in 2014 and 2015, respectively), they came from notably different social backgrounds. Şasa grew up in Istanbul and graduated from the prestigious Arnavutköy American Girls' College (Robert College). After being treated for a mental illness in 1973, she was diagnosed with schizophrenia and maintained a reclu- 
sive life for years. In 1981, she was introduced to Islamic mysticism through İbnü'l Arabi's The Ringstones of Wisdom (also translated as The Bezels of Wisdom; Fusüsu'l-Hikem) and announced that she was cured of her psychological problems with the help of these readings. Nar came from the provincial city of Kars in northeast Turkey, graduated from the Istanbul Advanced Islam Institute, and taught at various religious vocational high schools. He published his prose and poetry in periodicals, including Hakses, Millî Gazete, Yeni Devir, Pınar, Mavera, Yeni Sanat, Sedir, Çınar, Tohum, İslam, Millî Gençlik and Düşünce, and founded the Turkish branch of the World Islamic Literature Federation.

Given the intrinsic presence of ideological undertones in imagining a new world order and seen from a literary historical perspective, Ayşe Şasa and Ali Nar can be said to be following a tradition in their versions of Turkish utopian literature. Unlike their 19th-century Ottoman predecessors, they do not employ the dream format but opt for a rather more direct critique of the society created by the Republic. Yet, their criticism of the Republican inclination towards the West at the expense of losing the native lifestyle is still very much ideologically in line with them. Both writers are particularly critical of the abolition of the caliphate, which ended the global Islamic leadership of the Ottoman Sultan in 1924, as a part of the Republican drive towards secularization. Accordingly, they establish their utopian narratives through religious references and against the Western civilization. Consequently, the two novels are full of references to Islam and Christianity, as well as the narratives shared by both. Their Islamist utopias present their spatial settings in two specific forms: by pitching the West as an element for comparison and by founding these comparisons on monotheistic religious references. At a semantic level, both novels are based on a set of simplistic binary oppositions: East/West, Secular/Islamist, old order/new order, Christian/Muslim, past/present, corrupted place/idealized place and the like.

\section{THE WEST AGAINST THE WEST}

The connections between the chosen spatial settings of the novels and the ideologies of the novelists are too blatantly symbolic to ignore, which renders their political positions lacking in subtlety and refinement. In both works, the world of utopia is constructed upon an opposition against the West whereby the supremacy of the Islamist nation shines bright. In The Space Farmers, a Turkistan Islamic Republic is established after a legendary triumph in space conquest. In The Novel of the Monkeys, Vienna, a city that was in reality besieged by the Ottomans twice without success (in 1529 and 1683) and stopped the Ottoman advancement in Europe, is preferred as the setting for the corruption of civilization. The (probably unintended) irony in the choices aside, in both cases the idea of conquest emerges as being central to the utopias.

As announced on its cover, The Space Farmers was published as a "utopian space" novel in 1988. While its temporal setting is unclear, spatially it begins in a village in the eastern Turkish region of Malatya. Then a flashback to the 21st century reveals the space wars between two superpowers on Earth, named the West and the North. Their story is rounded up with how these two cruel superpowers weakened each oth- 
er through the wars and destroyed one another by means of the nuclear headquarters they built in space. The "enslaved" Earth nations in the East, particularly the Middle East, are thus freed from their chains and they finally manage to unite. The Palestine issue is resolved and the Jews who are wandering despondently in the desert have gone under the protective wings of the compassionate Islamist nation. The civil wars in the East are long forgotten, the Soviet Bloc states are gone, and the Turkistan Islamic Republic is founded. The European countries outside Islam, that is the Western world as defined by the writer, are being forced to surrender to the Islamist world with the pressure of the migrant workers arriving from the East.

Similarly, Ayşe Şasa's utopia is also set in the future and built upon the opposition between Western civilization and the Muslim world. The Novel of the Monkeys is set in the Vienna of 2075. Chaos, viruses and mental illness reign in the city and in such a climate of fear, everything is controlled by an authority. As in the early utopias of the Ottoman era, from the very beginning of the novel, material comforts, such as having access to all the delights, all the geographies and all the knowledge of the world with the push of a button, stand out as representations of Western modernity. The protagonist of the novel, Amadeus, lives in his modest civil servant's apartment on the 13th floor of a skyscraper and like the other residents in his buildings can live comfortably without ever going out of the building. So, Amadeus never leaves his home in the three months of the novel's narrated time and merely listens to the strange noises coming from outside his window.

Şasa builds her utopia on the strength of the recognizable yet alien spatial setting, the city of Vienna, the heart of European cosmopolitan culture and art:

The growling of orangutans that resound at the Pavlov Square... Police sirens that can be heard in short intervals... Especially the monkey-cry alarms of those in orange overalls... The chaos that rocks the bright Vienna morning... In its old name Vienna, in its new name XB21 has been being shaken up with new provocations for a while ([2004] 2019, 11). ${ }^{2}$

Three types of designated residents live in this utopian city, formerly known as Vienna but now called XB21: "the Monkeys", "the MDs" (that is, the mentally defective), and "the Humans". Monkeys believe that human beings have descended from monkeys, the MDs are immigrants, and the humans believe that they are created by God. In addition to these, there is another separate group called the "schizoids" who are suspected of not using their anti-depressants properly by "the universal police state", or who challenge their use.

The Space Farmers is built around the space journey of Hasan II, who is chosen by the World Islamist Federation Space Conquest Council as a representative of his race to live in space. Space Farmers, the name used for astronauts in the novel, do not feel the need to land on the Moon, because it is already polluted and corrupted by the West, and thus, is no longer a viable place. The Westerners are wearing space masks and living in tunnels like moles on the Moon and they are haphazardly disposing of their dead on its surface. As a result, the surface of the moon is filled with human skeletons. Their disposal of the dead as such is analogous to their position in the more advanced human civilization on Earth, now represented by the Islamist world: "If it goes on like this, 
the fools on the Moon would die off. [...] The World has changed. The Islamist World does not admit back to the Earth those whom the Westerners handpicked to send off to the Moon" (Nar [1988] 2015, 120-121). The reference to the foolishness of the Westerners living on the Moon is a reference by proxy to the foolishness of the Turkish secular statesmen who looked up to those Western fools.

The novel flashes back to 1969, the year in which the USA landed the first man on the Moon, to contrast the present state of the men on the Moon with its greenhouse-like tunnels in which humans lead plant-like lives. By 2040, births on the Moon have stopped and those who were already born have become wrinkly dwarves who are half a meter tall at the most and live maximum until the age of 30 . Their demise as such is a result of the bloodsucking Western superpower's godless civilization (120). If it were not for the destruction of the Western civilization in 2008 and the taking over of the Islamist Federation, that so-called civilization would have destroyed the Earth as well, just like the Moon. The destruction of the Moon is not just physical; it is also a moral corruption. This idea of moral corruption is established through highly problematic racial profiles in the story as the West's godlessness on the Moon is presented through its population of American and Russian Jews. The Moon is now an unholy place:

Because first of all, most of those on the Moon are American and Russian Jews. Secondly, they definitely carry the space disease. [...] Their foods are different, their languages, behaviors, tastes different... In a manner of speaking, they've become "fake space men" or "Moon savages"... Making the mistake of bringing them over to the ground would be like buying a trouble like the plague (121).

Instead, Refref II, the spacecraft that transports the Space Farmers, only films these somewhat mutated Moon Savages from a distance and transmits these broadcasts to Earth. The World Islamist Space Center decides to leave these mutated, monstrous Moon dwellers, who shall eat their dead, on the Moon until they become extinct.

What determines the meaning of place is the presence of those who interact with it as they transform the physical space into a place. In fact, the word for place in Turkish, mekân comes from the Arabic kevn, meaning both to exist and the place where something exists. When Hasan II discovers a solar system similar to the one his Earth belongs, he names it Solar II System and the planet he lands E.II, meaning the second Earth. This Earth II is an idealized prototype of the original Earth. Just like reflections in a mirror, these two planets are identical to each other. Hasan II designs this new Earth exactly like the original one he has left behind, in terms of geographical and religious regulations. He also continues to practice his faith precisely the way he used to. As such, he transforms this new world into his old world and maintains its values and structures in this new one. For instance, he fulfills the old ritual of Muslims' turning toward the sacred Kaaba on Earth to practice their prayers (namaz) wherever they may be by acting as if there is a Kaaba in this new world as well. As this new place is transformed into a version of the original Earth, its spatial categories and routines are also reproduced, and so it is Islamized. Seen in the context of the Turkish term mekân, Hasan II from The Space Farmers both exists in the new world that he has discovered and transforms that new world into a Muslim space under the guidance 
of the Quran. In The Novel of the Monkeys, however, salvation takes place in Capricorn Valley (Oğlak Çukuru), "in the mountainous area between the nightmare city and the region of immigrants that surrounds it, the place in a liminal space high up in a plateau", "calico curtains... A Muslim home adorned with colorful hand-woven carpets" (Şasa 2019, 89-61). In contrast to the grand vision of Ali Nar and his forceful transformation that reaches the skies, Şasa's version of Islamist salvation emphasizes a plain proposal of modesty and submission. The difference in their representations reveals their different versions of Islamism, in the case of the former a supremacist fundamentalism and in the latter a spiritual mysticism.

In The Space Farmers, when Hasan II returns to Earth from his successful space mission, he participates in a friendly football game between the "Islamist Front Federation" and the "Western Club", the mixed team of the Christian states. An American player in the Western Club, which looks like a Crusades Army, tries to kill Hasan II. This incident launches another war on Earth and the Center for Islam Federation shoots a missile to America and destroys the Statue of Liberty, known as "the Hatted Head" (Nar 2015, 182). With the destruction of the Statue of Liberty, the Islamist world sends a message to the Christian West: "The goal of the Islamist world is to bring you to your heels. Submit to Islam and be civilized. Otherwise, sooner or later we will stomp you out. Because civilization is superior morality" (182). The Islamist salvation, that is, the idea of jihad, and the destruction of the Western civilization interestingly foreshadows the attacks of September 11, 2001. In a matching parallel, in The Novel of the Monkeys, there is a Global Monkey Monument in the middle of the city. This monument is "a monkey that sits on a throne, holding a crystal globe in its hand, placed on an 8-meter gilded, cylindrical pedestal" (Şasa 2019, 63) and is presented to the reader as the symbol of "denial and forgetting".

Moreover, that the crown on the head of the Statue of Liberty in The Space Farmers is referred to as a hat establishes a parallel with the novelist's criticism of secular Turkey. One of the key cultural reforms following the declaration of the Republic was the passing of the Hat Law in 1925. The reformation of public clothing aimed at changing the daily practices of the Ottoman era directly and forced the people to wear Western-style clothing, resulting in much discontent among the traditionalist population. A similar critical reaction to the Republican reformations in civic life can be seen in The Novel of the Monkeys as well. Re-Re the Schizoid is one of those who try to spread Islam secretly in Capricorn Valley and is deemed "schizoid" by the state. However, Re-Re changes his name to Ruşen, which is a name of Persian origin and means enlightened. This depiction poses a critique of another key change following the foundation of the Republic, that is, the law regarding surnames. This law was passed in 1934, whereby everyone was required to pick a surname to replace their nicknames. The Surname Law is yet another move towards the establishment of a clear distance between the Republic and religion.

In The Space Farmers the Islamist Republic founded in the Far East, in the Philippines is not forgotten either. This Republic has gained power in Far East Asia and taken Japan, the equivalent of the West in Asia, under its control. As a predominantly Buddhist country, Japan is being punished separately from the Abrahamic religions 
in this fashion, because triumph, or more precisely, salvation is only possible through a monotheistic religion like Islam. In the novel, the utopia of Islamist unity is achieved from 2008 onward and powerful intercontinental Islamist economic unions have been built through collective headquarters. With the conquest of space, the distance from the Christians will grow and the strong light of Islam will be sovereign.

At the end of the novel, Ali Nar takes us for a walk around Istanbul in 2048. The city is rebuilt and transformed into a totally different place from what it is like in 2021. It is re-designed in the images of the Tulip Era (1718-1730) of the early Ottoman modernity and the period of its conquest by Mehmed II (the Conqueror) in 1453. It is a city of large squares and wide boulevards with places of prayer in their midst: "There were large squares, green spaces and wide boulevards, wide enough for planes to take off and land. [...] The things that stood out the most were places for namaz in the middle of the big parks" (Nar 2015, 185). In 2008, during the war of the superpowers, the entire city had been destroyed due to the alliance of the period's politicians with the West. In a divine miracle, only the mosques remained intact, while the representatives of secularism, such as schools and apartments were flattened to the ground. In the redesigned Istanbul, none of the Western symbols from before 2008 exists. The novelist re-designs the entire place as a place of worship with "the central platform of the park, the symbol of God Almighty, a huge dome" (185).

Bülent Somay argues that considering utopia as merely a literary genre would leave our perspective wanting. He writes, "utopian fiction lies at the midpoint of a triangle whose corners are philosophy, politics and literature" (2010, 33). From a political perspective, the two novels share the belief that Western civilization and the science that it produced are a threat against the order of the world. As a response to that threat, they utilize the genre of utopia in the image of their own ideological ideals, namely, a radical Islamism (in the case of Nar) and a mystic spirituality (in the case of Şasa).

\section{REFERENCES TO THE ABRAHAMIC RELIGIONS}

In both novels, religious motifs and references from the Bible and the Quran are used alongside each other. In The Space Farmers, the prophets - as they are referred to in Islam - portrayed in the Torah, Bible, and Quran, particularly Christ (Is $a$ in Turkish, as in Arabic), are mentioned. The choice of Christ often emphasizes what came after him as the true faith, that is, Islam. The most important mission of the space journey is for space to be cleansed of infidels. The principle purpose of the Islamist Federation in this respect is to prepare the world in an Islamic fashion for Christ's return as the Messiah. In the novel, we see that Christ is embraced as a prophet as pronounced in the Quran, and since the path of all prophets is Islam, naturally so is that of Christ as one. Ali Nar quotes the surah of Al-Imran to establish this link:

And he called the Christian World back to Islam. He mentioned that the descent of Christ is nigh and said "Come to a word that is just between us and you, that we worship none but Allah, and that we associate no partners with Him, and that none of us shall take others as lords besides Allah" $(2015,156)$. 
The journey to the unknown is a very common motif since the pioneer of the genre of utopia, Thomas More. The location of utopias somewhere between reality and fiction is associated with the starting place of utopia's traveller being a real place and this person's visitation of an imagined one and returning home (Vieira 2010, 8). Before his space journey, Hasan II is trained by the religious scholar Mullah Hamit. It is a spiritual training for the preparation of the body for the space journey and is linked to miraj, which is both a spiritual and a bodily journey meaning to ascend. It has a very significant place in Turkish Islam and refers to Prophet Muhammad's ascension to the heavenly spheres. Moreover, the spacecraft's name Refref in Arabic is also significant since it is the vehicle that will elevate the Prophet to the heavens during Ascension (Taşpınar 2007, 534). The speed of light that is achieved in space is called Speed of Alborak after the name of the horse that will carry the Prophet again during ascension. These renamings by the novelist display his Islamization of the scientific advancements invented by the West and a key component of his exhibition of Islamic power and sovereignty.

In The Novel of the Monkeys a character called Maniac Archimedes, who is suspected of dissent by the universal police, experiences an internal miraj. Şasa depicts him "ascending in his orange monkey outfit and with the tiny bells jingling at the tip of his tail. He was someone who has managed, to an extraordinary extent, to transcend the contrast between his outer appearance and inner world" (2019, 77). This human in ascension lives in his "cave that smells of grass, earth and incense". The humans who live in the caves in the novel are linked symbolically to Prophet Mohammad in reference to the visitation of Gabriel when he was in the cave to be informed of his divine duty as the prophet. The utopian place is thus divided in two: Vienna, where Monkeys who do not believe in Islam live, and the cave and its surroundings outside the city, where Muslims live. The choice of place being in the heart of Europe instead of Anatolia is linked with the novelist's desire to locate and connect the Monkeys with Europe as a form of criticism and in response to Republican Turkey's turning toward the West for innovations. Those who do not believe in Islam are both Monkeys and mentally ill, and their living spaces constantly reinforce their illness. In the zoo, humans who are defined as Monkeys live in cages, like animals.

In The Space Farmers, all the space research is done under the guidance of the Quran. Verses from the Quran are used as epigraphs at the beginning of the chapters. The true goal of this "Islamist utopia" is to prove the guiding force of Quran not only on Earth but also in space. In this context, the novelist's choice of Space Farmers to refer to the astronauts is rather telling in understanding the relationship he establishes with the Quran as well as Christianity. In the Al-Fath surah of Quran it says that Prophet Muhammad, like a farmer, sows the seeds of Islam in clean earth, that is, in clean hearts and talented minds. Initially sown in the minds of a few people, Islam grows like an avalanche and gains strength in a short time:

This is their description in the Torah. And their parable in the Gospel is that of a seed that sprouts its "tiny" branches, making it strong. Then it becomes thick, standing firmly on its stem, to the delight of the planters - in this way Allah makes the believers a source of dismay for the disbelievers. To those of them who believe and do good, Allah has promised forgiveness and a great reward (Al-Fath 48:29). ${ }^{3}$ 
In some readings of the Quran this section is linked to the parable in the Gospel of Matthew 13:3-8, "A farmer went out to sow his seed. As he was scattering the seed, some fell along the path. [...] Still other seed fell on good soil, where it produced a crop - a hundred, sixty or thirty times what was sown. Whoever has ears, let them hear" (Karaman et al., 2020, 82-83). ${ }^{4}$ In Ali Nar's novel, that is science fiction, the Space Farmers will sow the seeds of Islam in space and make it grow. In Şasa's The Novel of the Monkeys, however, people dream of "Turbaned beings in loose gold embroidered caftans descend from the skies and appear in the world, spread in groups to the four quarters; the nightmare city comes under the control of these beings" $(2019,92)$.

While the apparent mission of the space program is to discover new planets, the Space Farmers have a top secret mission as well. As soon as Refref II takes off, this mission is presented to the space farmers on board. Each passenger carries a capsule of in vitro fertilization, alongside the plant seeds and animal cells, in order for them to breed and multiply in "the Land of the Lights", that is, the worlds they will discover in space: "You can think of Refref II as a Noah's Ark. The substance of the whole world is with you. If the entire life on Earth was destroyed, it can be rebuilt on your return. Of course, God willing" (Nar 2015, 98). In an analogous fashion, The Novel of the Monkeys also has the theme of rebirth based on its idealized redesigning of space. The cave outside the city represents a form of rebirth against the madness and the chaos of Vienna. Upon the loss of minds and corruption of souls among the Monkey people, it will be the Islamist faith and the Quran that will be the salvation of the people between sanity and insanity. Therefore, those who believe in Islam, live in their caves outside the city, use herbs for healing instead of medication and lead a secret albeit healthy and peaceful life outside the "modern" life of the city.

Both novelists position Islam and modernity in opposition in their desire to establish new world orders and state systems. The state should be run under the Quranic Law (Sharia) just as it was in Ottoman times. Edward Said discusses the literature in the Muslim world along these lines:

Thus, since the central text [Koran] is in Arabic, and since, unlike the Gospels or even the Torah, it is given as unitary and complete, textual traditions are essentially supportive, not restorative. All texts are secondary to the Koran, which is inimitable. [...] The Prophet is he who has completed a world-view; thus the word heresy [emphasizing by E.S.] in Arabic is synonymous with the verb "to innovate" or "to begin". Islam views the world as a plenum, capable of neither diminishment nor amplification. Consequently, stories like those in The Arabian Nights are ornamental, variations on the world, not completions of it; neither are they lessons, structures, extensions, or totalities designed to illustrate either the author's prowess in representation, the education of a character, or ways in which the world can be viewed and changed (1975, 199-181).

As can be seen in this definition, in The Novel of the Monkeys, life as defined in the Quran is already a utopia, which is epitomized in the metaphor of the cave as the place where Prophet Mohammed received the word of God and the verses from the Quran for the first time. The cave, just like the mother's womb, will be where the Islamist state will grow. This transformation is presented through the idea of "healing" 
in the novel, finding the path to wellness: "It was almost as if the healing had started first in his heart and then was reflected in his mind, and eventually took over his entire being" (Şasa 2019, 92). Here healing is related to mental health, those who heal will no longer be insane. In The Novel of the Monkeys, society outside the Islamist model is associated with madness whereas life according to the Quran with peace. As such, the cave as a space of utopia is a highly political symbol. It represents both darkness and light and bears a double-layered meaning. It is dark because it bears the traces of the new order to come, but it is light because an Islamist state will come out of it.

\section{REVERSALS}

In both The Space Farmers and The Novel of the Monkeys the regime established in the utopian places in accordance with Islam and Quran is fueled by an anti-Western perspective and demolishes Western symbols. Ayşe Şasa already declares the conquest of Vienna by Islam through her depiction of it as belonging to Islam. In Ali Nar's novel, the West is depicted as being "old and sick" $(2015,37)$ yet still maintaining some of its technical advantages. Even if they are unable to find cures for illnesses, they are competing to make the old young again and they are searching for a cure against death. The phrase "the sick man of Europe" as first used by the Western powers against the Ottoman Empire at the end of the 19th century and it was quickly embraced by the whole of Europe. In the 21st century as depicted in the novel, the "sick man" refers to the Western world, meaning the West is facing its decline in the same way the Ottoman Empire was two hundred years ago. Ayşe Şasa's choice of Vienna as the utopian place in her novel is thus highly symbolic in terms of this shift of power.

The representation of the West as "the old and sick man" in Ali Nar's novel is matched by the portrayal of the Monkeys in Ayșe Şasa's work. Westerners are the Monkeys because they believe in Darwin's theory that humans descended from monkeys, against the "truth" that God has created the humans. The Monkeys are unable to see the "truth" as such. Nar's reversed "sick man" allusion in his presentation of Islam as a force to reckon with is also paralleled by Şasa's depictions of "human-made" cyborgs, alongside mentally ill people who disturb the social order. Moreover, similar to the utilization of the "sick man" idea in the novels, other symbols of the West are reversed in both works. The cave image in The Novel of the Monkeys is a good example of such reversal. From Plato's cave allegory to Freud's womb metaphor, it combines the meanings of various births and re-births in a way that reverses their Western foundations. In the novel, the cave is located outside of Vienna, separate from its socalled civilization because those civilized people who live in Vienna are mentally ill. This reversal of meanings in regards to utopian locations is invested in irony against a Western romanticism via its connections to Freud and the foundations of his psychoanalytic theory. Through such uses of space, religion and utopia are put against one another to construct their unique albeit ideologically fraught utopian vision. The jarring contrast between the believers who live outside the city and in peace with nature and the Monkeys who live in the city not daring to venture out maintains the novel's strongly anti-Western perspective. In contrast to the darkness in the cave, Amadeus's flat is brightly lit. However, from a spiritual perspective it is darker than the cave, 
because the latter is illuminated by the hearts and the inspiration of its residents not by some man-made lighting system. In that sense, the utopian location of the cave is linked to the choice of Vienna and its outskirts to further reinforce the established reversals: it is Freud's Vienna against the cave of Islam, Freud's unconscious versus the spiritual inspiration from the word of God. For the former, theirs is a state of madness, for the latter, it is a sign of healing.

As such, the cave is not just a metaphor but also a challenge to the tradition of Western utopian writing. Despite its tabula rasa appearance, the cave is scripted with many layers of God's word and inspiration, it is the presence of Islam, against the futile promises of heaven on Earth in utopian writing. The use of illustrations on every page also speaks for such a difference. Utopia presents what can be visualized; however, the cave prevents depiction. Utopia is a genre shaped by the human mind, but faith transcends the mind, for the mind is incapable of comprehending the divine.

\section{CONCLUSION}

Both The Space Farmers and The Novel of the Monkeys utilize the utopian space as a device to return to the "essence". The novelists propose that modern life is defined by Western values and those Western values distance Muslim societies from their "essence". This kind of conservative thinking has prevailed in Turkey since the late 19th century. The literary intellectuals of Ottoman modernization in that period, such as Namik Kemal and Ahmet Mithat and those in the early Republican era, such as Peyami Safa and Yakup Kadri, particularly emphasize how the Western lifestyle should not be allowed to corrupt native values (Mardin 2006, 135-163). As such, the ideas that both novelists present in their works parallel these earlier attitudes and their utopian places become strong political elements. In The Space Farmers, Ali Nar calls his fictitious country the Turkistan Islamic Republic and constructs an Islamo-Fascist world. The reactionary and militarist discourse that dominates the entire novel reveals hate speech against Jews, Christians, and Westerners and it declares a crusade against not only the modern Turkey established in 1923 but also against all Western countries. The writer in a way takes his revenge on the country's secular transformation through Istanbul's Taksim Square. In a symbolism that is even more meaningful today (after the Gezi Protests of 2013), ${ }^{5}$ in the novel the Square is cleansed of all the Western influences after 2008, including the Atatürk Cultural Centre that used to hold the main state stages for theatre, opera and ballet.

In both novels, technology plays a great part in the representations of utopian spaces. In The Novel of the Monkeys, technology represents all that is bad in the Western civilization, whereas in The Space Farmers, it is under the control of Islam but is cleansed of everything that is "superstitious". While the cave symbolizes the birth of Islam in The Novel of the Monkeys and thus becomes the home of the spiritual world promised by faith, bearing political significance, in The Space Farmers the utopian place only becomes home with the presence of Muslims and their symbols. In Şasa's novel, the Muslims long for the "old home" once ruled by Islam. Seen in terms of the relationship between the utopian place and religion, she constructs it far away from the city, civilization, chaos and nightmare. For Ali Nar, on the other hand, any place 
and space become Islamized under the guidance of the Quran. Everything that Muslims create in accordance with the Quran represents that which is good and beautiful. Believers of other faiths, particularly the Jews, are pushed out to other planets, imprisoned in dystopian places in a universe ruled by Islam. Utopian places can be created only by those who defend Islam and they thus represent the good in them.

The representation of technology as chaos in the novels is also a criticism of the secular state that was established in 1923, the Turkish Republic that left out Islam. The old country as the land of the Muslims was turned into hell and the new life of the new state brought them closer to the West. Such proximity transformed the country into a dystopian land, a homeland invaded by the Jews and the Christians where Muslim way of living is not practiced anymore. By bringing the lifestyle dictated by Islam, all the so-called modern lies and illusions will be discarded and the homeland will become a utopian land once again. From such a perspective, reducing the West merely to its technological advancements renders a rejection of the Republican regime in Turkey possible. The utopian place constructed through technology is posed as the opposite of what Islam recommends. This opposition proposes the search for utopia not in what exists or imagined but beyond what can be imagined, in the Islamist faith and in the practices following the Quran. As such, the utopian place becomes a political element and a symbol for the success of jihad in all aspects of life.

\section{NOTES}

1 For an outline of the distinction between Islam as a belief system and Islamism as a radical ideology, see Toumi 2011.

2 All translations from Turkish are by the present authors.

3 From Mustafa Khattab's translation of the Quran, The Clear Quran. Available at https://theclearquran.org.

4 For the English translation of Karaman's quote, the New International Version of the Bible is used. Available at https://www.biblestudytools.com/niv/.

5 The Gezi Park demonstrations took place in Istanbul between May 25 - June 15, 2013 as part of a campaign against the redevelopment of the Taksim area (symbolized by the planned destruction of the park's trees, one of the last remaining green spaces in the city center) and later spread nationwide. See Yigit Turan 2017.

\section{LITERATURE}

Gökşen, Erol. 2015. “Uzay Çiftçileri ve Şebek Romanı’nda Ütopya ile Distopyanın Tezahürü.” In Edebiyatın izinde Fantastik ve Bilimkurgu, ed. by Seval Şahin, Banu Öztürk, and Didem A. Büyükarman, 188-194. Istanbul: Bağlam Publishing.

Karaman, Hayreddin, Mustafa Çağrıcı, İbrahim Kâfi Dönmez, and Sadrettin Gümüş, eds. 2020. Kuran Yolu Tefsiri. Istanbul: Türkiye Diyanet Vakfı Publishing.

Khattab, Mustafa. 2016. The Clear Quran. Lombard: Furqaan Institute of Quaranic Education.

Mardin, Şerif. 2006. Religion, Society, and Modernity in Turkey. New York, NY: Syracuse University Press. Nar, Ali. [1988] 2015. Uzay Çiftçileri. 2nd ed. Istanbul: Elif Publishing. 
Said, Edward. 1975. Beginnings. New York, NY: Columbia University Press.

Şasa, Ayşe. [2004] 2019. Şebek Romani. 5th ed. Istanbul: Timaş Publishing.

Somay, Bülent. 2010. The View from the Masthead: Journey Through Dystopia Towards an Open-Ended Utopia. Istanbul: Bilgi University Press.

Szyska, Christian. 1995. "On Utopian Writing in Nasserist Prison and Laicist Turkey." Die Welt des Islams (New Series) 35, 1: 95-125.

Taşpınar, İsmail. 2007. "Refref." In Islam Ansiklopedisi, 534-535. Istanbul: Türkiye Diyanet Vakfı Publishing.

Toumi, Alek Baylee. 2011. "Literature and Power: Muslims Vs. Islamists." Religion \& Literature 43, 1: 126-132.

Vieira, Fatima. 2010. “The Concept of Utopia." In The Cambridge Companion to Utopian Literature, ed. by Gregory Clayes, 3-27. Cambridge: Cambridge University Press.

Yigit Turan, Burcu. 2017. "Occupy Gezi Park: In Search of a Public Space, Democracy and Alternative City Making." In City Unsilenced: Urban Resistance and Public Space in the Age of Shrinking Democracy, ed. by Jeffrey Hou, and Sabine Knierbein, 83-93. New York, NY: Routledge.

\section{The Islamist version of utopia: The politics of redesigning space}

Islam. Utopia. Place/Space. Ali Nar. Ayşe Şasa. Western civilization.

This article examines utopian novels by two Islamist Turkish writers: Ali Nar's The Space Farmers (Uzay Çifţileri, 1988) and Ayşe Şasa's The Novel of the Monkeys (Şebek Romani, 2004), which were celebrated among Islamist circles upon their publication. In these two novels, the corruption and pollution of place/space is blamed upon the "Christian" Western civilization. They depict how the desired regime change will begin in Turkey and expand towards Europe and then to the rest of the world, through the portrayal of oppositional places as utopian/dystopian spaces. The article discusses the ways in which space/place is ideologically redesigned in the Islamist imagination as a political symbol and analyze how these popular Islamist writers present the world and the space for their utopian vision of Islamist supremacy.
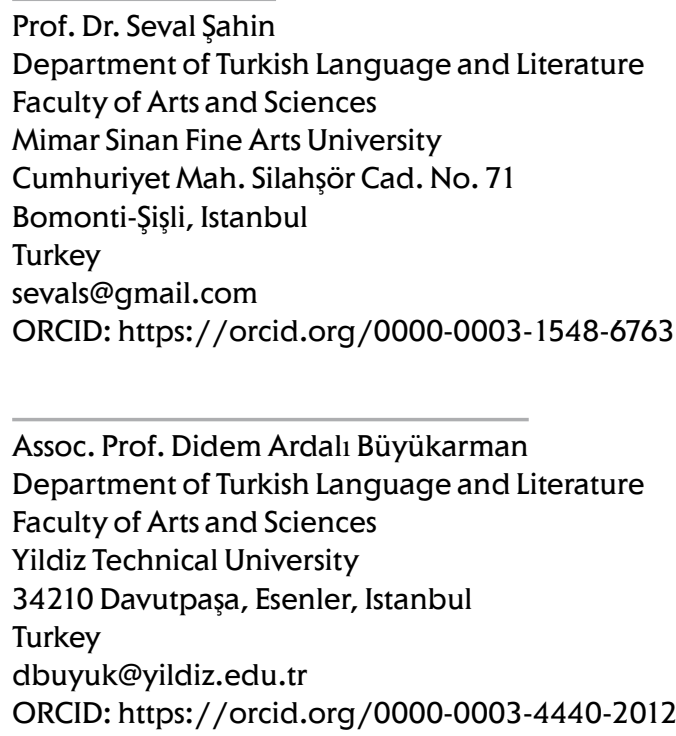